\title{
RESEPSI REMAJA TERHADAP DAMPAK \\ PERGAULAN BEBAS DI DALAM FILM DUA \\ GARIS BIRU
}

\author{
Mahardiansyah Suhadi \\ Ilmu Komunikasi dan Desain \\ Universitas Adhirajasa Reswara Sanjaya \\ Bandung \\ mahardiansyah30@gmail.com \\ Rafly Pratama \\ Ilmu Komunikasi dan Desain \\ Universitas Adhirajasa Reswara Sanjaya \\ Bandung \\ raflypratama31@gmail.com \\ Rifky Anindya Yusuf \\ Ilmu Komunikasi dan Desain \\ Universitas Adhirajasa Reswara Sanjaya \\ Bandung \\ rifky.anindiya@gmail.com
}

\begin{abstract}
The film is one of the mass communication media which has a big influence on society at large. a film is also a form of a message consisting of various symbols and signs that form a meaning system so that it can be interpreted by each person differently, depending on the person's reference and ability to grasp the meaning conveyed. The film Dua Lines Biru by Gina S. Noer takes the theme of teenage pregnancy in promiscuity. The purpose of this study was to analyze the reception of adolescent audiences on the impact of promiscuity in the film Dua Garis Biru. This research uses a qualitative method with an analytical approach to encoding and decoding theory from Stuart Hall, which observes the audience's position on the meaning of a work. An understanding of the impact of promiscuity in the film Two Blue Lines. The results of this study the audience dominates the Hemegony Position which means the message is conveyed and the audience accepts the meaning or message as it is. But several scenes are in the Negotiated Position and Oppositional Position because the informant has its own alternative meaning or reference in certain scenes.
\end{abstract}

Keywords: Theory Reception, Dua Garis Biru, Stuart Hall 
Abstrak. Film merupakan salah satu media komunikasi massa yang memiliki pengaruh besar terhadap masyarakat luas. Film juga merupakan bentuk sebuah pesan yang terdiri dari berbagai simbol dan tanda yang membentuk sebuah system makna sehingga bisa diinterpretasikan oleh setiap orang secara berbeda-beda, tergantung kepada referensi dan kemampuan orang tersebut dalam menangkap makna yang disampaikan. Film Dua Garis Biru karya Gina S. Noer mengangkat tema kehamilan remaja di dalam pergaulan bebas. Interpretasi konflik dalam adegan film ini menjadi latar belakang penelitian untuk melihat resepsi penonton atau masyarakat dalam menonton film Dua Garis Biru. Tujuan penelitian ini adalah untuk menganalisis resepsi penonton remaja terhadap dampak pergaulan bebas dalam film Dua Garis Biru. Penetilian ini menggunakan metode kualitatif dengan pendekatan analisis teori encoding dan decoding dari Stuart Hall yang mengamati tentang posisi penonton terhadap pemaknaan suatu karya. Pemahaman tentang dampak pergaulan bebas dalam film Dua Garis Biru. Hasil penelitian ini penonton mendominasi Hemegony Position yang berarti pesan tersampaikan dan penonton menerima makna atau pesan tersebut dengan apa adanya. Tetapi ada beberapa adegan yang berada didalam posisi Negotiated Position dan Opositional Position karena informan memiliki makna atau acuan alternatif tersendiri pada adegan tertentu.

\section{Keywords: Teori Resepsi, Dua Garis Biru, Stuart Hall}

\section{PENDAHULUAN}

Era globalisasi yang ada pada saat ini mempengaruhi kompleksitas sistem sosial budaya yang terdapat dalam masyarakat. Perkembangan media massa pun semakin pesat ketika terjadi perubahan dramatis dan dinamis dalam teknologi komunikasi. Pesatnya kemajuan sistem teknologi informasi ini telah memberikan dampak negatif maupun positif terhadap perubahan global yang signifikan bagi pola hidup manusia. Komunikasi massa juga merupakan komunikasi yang menggunakan media massa, baik itu media cetak ataupun media elektronik. Komunikasi massa bisa didefinisikan juga sebagai suatu proses komunikasi yang berlangsung dimana pesannya dikirim dari suatu perusahaan yang melembaga atau individu kepada masyarakat yang sifatnya global atau umum melalui media cetak atau elektronik yang bersifat mekanis contohnya seperti televisi, radio, internet, surat kabar, dan lain - lain. (Tambunan, 2018)

Komunikasi massa berasal dari pengembangan kata media of mass communication (media komunikasi massa). Media yang dimaksud merupakan alat yang digunakan untuk mengirim pesan dari pengirim kepada penerima. Di dalam komunikasi massa, media adalah penghubung antara pengirim dan penerima yang sifatnya terbuka atau transparan, dimana setiap orang bisa melihat, membaca, dan mendengarkan. Menrutu Nurudin Media cetak adalah media yang bersifat statis dan 
mengutamakan pesan visual, di dalam media ini terdiri dari lembaran kertas dengan gambar, dan sejumlah kata dengan tata warna halaman putih (Malang, 2012). Media cetak berisi dokumen atas segala ucapan yang dikatakan orang lain atau narasumber dan rekaman peristiwa yang diperoleh oleh jurnalis dan diubah dalam bentuk kata, gambar, dan sebagainya. Media massa yang merupakan media cetak adalah majalah, buku, surat kabar dan sebagainya. Sedangkan media elektronik merupakan media yang menggunakan alat-alat elektronik modern. Media elektronik dapat menarik masyarkat untuk memberikan suatu perhatian secara penuh karena apa yang disiarkan dan dilihat tidak dapat diulang karena bersifat langsung. Media elektronik bersifat demokratis karena media elektronik mencakup luas secara keseluruhan, bukan hanya dari kalangan tertentu saja. Media massa yang merupakan media elektronik adalah film, radio, internet dan televisi. Seperti penjelasan di atas menurut Effendy Film adalah media komunikasi yang bersifat audio visual untuk menyampaikan suatu pesan kepada sekelompok orang yang berkumpul di suatu tempat tertentu. Film bisa menjadi pesan didalam media komunikasi massa yang bisa berbentuk apa saja tergantung dari tujuan film tersebut. Tetapi pada umumnya suatu film dapat mencakup berbagai pesan, baik itu pesan hiburan, sosialisasi, pendidikan dan informasi. (Malang, 2012)

Film juga bisa dianggap sebagai media komunikasi ampuh terhadap masyarakat yang menjadi sasarannya, karena sifat dari film sendiri yaitu audio visual, film bisa bercerita banyak dan dibentuk dalam waktu singkat. Ketika menonton film, penonton akan merasakan seakan menembus ruang dan waktu dan dapat mempengaruhi penonton atau audiens. Film pada dasarnya dapat dikelompokan menjadi dua bagian dasar, yaitu kategori film cerita dan non cerita. Pendapat lainnya menggolongkan atau membagi film menjadi film fiksi dan non fiksi. Film fiksi adalah film yang dibuat atau diproduksi berdasarkan cerita yang dibuat atau dikarang oleh penulis dan diperankan oleh aktor dan aktris. Pada umumnya film fiksi atau film cerita dibuat bersifat komersil, artinya film ini akan dipertunjukan atau diputar dibioskop dengan harga karcis atau tiket masuk variatif dan mendapatkan dukungan sponsor iklan dan lain - lain. Pengertian film secara mendasar yaitu sinema, dijelaskan yakni cinemathographic yang berasal dari kata cinema dan tho/ "phytos" yang memiliki arti cahaya sedangkan graphic memiliki arti yaitu tulisan/ citra/ gambar, dapat dikatakan film tersbut memiliki arti melukiskan suatu gerak dengan cahaya. Film adalah salah satu media visual yang sangat berkembang di Indonesia, bahkan penikmat atau penyuka film dapat terinspirasi hidupnya sebagai efek pribadi dari film yang mereka sukai. Film dapat bermakna jika bertemu dengan para penontonnya, Oleh karena itu antusias para penonton sangatlah dibutuhkan ketika menyaksikan film Indonesia karena dapat menjadi hal yang sangat penting. Perkembangan film di Indonesia kini mengalami perkembangan dan kemajuan yang begitu pesat, dilihat dari jumlah para penonton sinema nasional yang merangkak naik. Jika pada sekitar tahun 2000 target pasar untuk film nasional hanya mencapai 7,46 persen, maka ditahun 2008 mengalamin 


\section{RESEPSI REMAJA TERHADAP DAMPAK PERGAULAN}

BEBAS DI DALAM FILM DUA GARIS BIRU

kenaikan yang begitu sangat besar hingga mencapai 50 persen (Servia 2007, dikutip Barker 2011) dalam (Kartika, 2017).

Menurut Joseph sebuah karya tentunya tidak akan pernah lepas dari siapa yang membuat karyanya atau bisa kita sebut sebagai penciptanya, karena karya ini bersifat mutlak dan tidak dapat diambil alih oleh siapapun (Kartika, 2017). Berbagai jenis karya dapat kita temui pada sebuah karya sastra dan film, seperti puisi, novel, pantun, drama bahkan roman. Dari berbagai karya yang ada nampaknya novel yang lebih banyak untuk memberikan suatu ide terhadap para pencipta layar lebar, respon masyarakat dalam mengapresiasi suatu karya tentunya sangat beragam, karena masyarakat berperan sebagai penonton sehingga masyarakatlah yang memiliki peran penting untuk menikmati apa yang disuguhkan dimata mereka, Film merupakan sebuah media yang bisa menampilkan kejadian yang sebenarnya ke dalam sebuah layar lebar.

Menurut Sumarno Film non cerita adalah film yang mengambil kenyataan sebagai subyeknya, yaitu merekam kenyataan dari pada fiksi tentang kenyataan (Malang, 2012). Film juga bisa menjadikan gambaran atas suatu realitas sosial yang dapat kita temukan sehari-hari. Dalam pembuatan film pun harus memiliki sentuhan-sentuhan yang berkaitan dengan unsur seni sehingga dapat menjadi suatu film yang memiliki pesan moral terhadap masyarakat. Budaya dalam masyarkat dapat tersampaikan dalam sebuah film yang didalamnya memiliki sentuhansentuhan unsur seni. Film yang berkualitas memang terbilang sulit untuk dipahami, tetapi tidak terlalu sulit untuk dirasakan. Berkualitas atau tidaknya sebuah film sebenarnya bergantung dari perspektif setiap individu yang bersifat subyektif. Semuanya kembali lagi kepada selera para penonton atau setiap individu. Begitu juga dengan film-film yang berada di Indonesia kini memiliki banyak genre dan cerita yang beraneka macam seperti genre komedi, drama, action, horror, fantasy, thriller, musical, adult, sci-fi, cult, animation dan documentary. Dari bermacammacam genre film diatas, film Dua Garis Biru termasuk kedalam kategori film drama yang mengusung tentang pergaulan bebas remaja dimana pesan yang disampaikan dalam film ini menyampaikan keresehan orang tua terhadap situasi pergaulan remaja saat ini. Dimana film ini bercerita mengenai kisah cinta remaja yang diperankan oleh Bima (Angga Yunanda) dan Dara (Zara JKT48) yang masih duduk di bangku Sekolah Menengah Atas (SMA). Dimana mereka saling mencintai dan melengkapi satu sama lain, hingga akhirnya mereka melanggar batasan yang mengakibatkan hamil di usia dini. Yang membuat kedua keluarga merasa gagal dalam mendidik anaknya, dan pada akhirnya mereka harus menerima konsekuensinya dan menikah pada usia dini. Setelah menikah munculah masalah sedikit demi sedikit, tidak hanya diantara Bima dan Dara tetapi permasalahan muncul diantara kedua belah pihak keluarga mereka. Kemunculan film ini mendapat antusias dari para penonton Indonesia karna mengusung tema yang berkaitan dengan isu atau keresahan orang tua terhadap anak dan edukasi seks kepada para remaja di Indonesia, 


\section{RESEPSI REMAJA TERHADAP DAMPAK PERGAULAN}

BEBAS DI DALAM FILM DUA GARIS BIRU

Berdasarkan dari penjelasan isi film di atas, maka edukasi mengenai seks pranikah menjadi sangatlah penting untuk kita pelajari sejak dini agar dapat mengurangi segala macam resiko yang dapat menimbulkan kehamilan di usia muda. Banyak hal yang dapat dirugikan jika kita melakukan perilaku seksual pranikah, karena dapat menyebabkan kerugian terhadap diri sendiri maupun orang disekitar kita. Edukasi seksual ini tidak hanya bisa kita dapatkan melalui pendidikan di sekolah saja melainkan banyak sumber lainnya yang dapat menambah wawasan kita mengenai edukasi seksual yang dapat kita peroleh melaluli internet serta dapat kita peroleh melalui film dengan melihat makna yang terkandung didalam visualnya. Pada zaman sekarang, film-film di indonesia sudah mulai memunculkan kualitas film yang sangat baik serta memiliki bermacam-macam makna edukasi seperti salah satunya yaitu tentang edukasi seksual. Film dapat dikemas sedemikian rupa dengan tujuan untuk memudahkan para penonton agar dapat memahami isi film yang mereka tonton sehingga akan menimbulkan berbagai macam sudut pandang dari setiap penontonnya. (Syarifa \& Nugroho, 2020) Film ini mendapat respon yang variatif dari para penontonnya, sehingga menimbulkan pro dan kontra dari masyarakat, untuk sebagian masyarakat ketika melihat tayangan trailernya film ini dicurigai membawa dampak negatif bagi para penontonnya khususnya remaja, karena memperlihatkan pasangan remaja yang sedang berada diatas ranjang. Maka kontroversi ini semkain menjadi hingga ada masyarakat yang demo dan membuat petisi agar film ini tidak ditayangkan di bioskop, Namun disisi lain sebagian penonton malah merespon positif karna film ini bisa membuat para orang tua membuka mata dan pikirannya untuk lebih mengawasi dan memperhatikan anak anaknya untuk lebih waspada terhadap pergaulan remaja saat ini.

Dibalik terjadinya kontroversi, film "Dua Garis Biru" akhirnya mampu menarik banyak penonton dari berbagai kalangan usia remaja hingga dewasa, para penonton kini dapat memahami makna yang terkadung didalam setiap adegan-adegan yang berada di film "Dua Garis Biru" tentang bahayanya pergaulan remaja terhadap seks pra-nikah yang dilakukan didalam film tersebut. Khalayak sebagaimana yang telah disampaikan oleh Turner, media dapat digunakan untuk merefleksikan ketertarikan terhadap prefensi atau hal yang lebih disukai. (Syarifa \& Nugroho, 2020). Namun, menurut Baran, khalayak dapat menolak pengaruh-pengaruh yang disebabkan oleh media jika terjadi ketidak seimbangan atau adanya jarak yang terjadi di tengah masyarakat dan pertentangan dengan pemahaman lainnya sehinggap dapat menganggap orang lain dapat menerimanya begitu saja dalam memahami suatu makna hanya untuk mengikuti apa yang media inginkan. (Syarifa \& Nugroho, 2020).

Film "Dua Garis Biru" berhasil memperoleh prestasi dan berbagai macam respon sudut pandang masyarakat sejak awal penayangannya pada tanggal 11 juli 2019 di bioskop. Pada saat penayangan hari ketujuhnya di seluruh bioskop Indonesia, film tersebut mampu menarik perolehan penonton sebanyak 1.235.354 penonton dari berbagai kota di Indonesia. Selain itu film tersebut juga masuk 


\section{RESEPSI REMAJA TERHADAP DAMPAK PERGAULAN}

BEBAS DI DALAM FILM DUA GARIS BIRU

kedalam lima nominasi dalam acara Festival Film Bandung 2019, serta menduduki tempat sebagai pemenang film bioskop terpuji, film bioskop dengan penata artistic terpuji, dan film bioskop dengan penulis scenario terpuji. Hal ini tentunya dapat membawa film "Dua Garis Biru" menempati deretan posisi kedua film terlaris di Indonesia pada tahun 2019 setelah posisi pertama yang ditempati oleh film "Dilan 1991" yang dapat menarik perolehan penonton sebanyak 5.253.411 penonton. Selain mendapatkan beberapa nominasi di Festival Film Bandung, film "Dua Garis Biru" juga berhasil memperoleh beberapa penghargaan di acara "JAFF-ISA (Jogja Asian Festival Film-Indonesian Screen Awards) sebagai Film Terbaik JAFF-ISA 2019, SutraDara Terbaik JAFF-ISA 2019, dan Penulis Naskah Terbaik JAFF-ISA 2019. Film ini juga mendapatkan penghargaan lainya dalam acara Festival Film Indonesia yang diantara lainnya yaitu memenangkan "Penulis Skenario Terbaik" oleh Gina S. Noer dan mendapatkan "Pemeran Pendukung Wanita Terbaik FFI 2019" oleh Cut Mini. Film Dua Garis Biru juga ternyata memperoleh lima nominasi di acara "Festival Film Tempo" yang diantaranya yaitu sebagai "SutraDara Pilihan Tempo (Gina S. Noer)", "Film Pilihan Tempo (Dua Garis Biru), "Aktor Pendukung Pilihan Tempo (Cut Mini Theo)", "Aktor Pilihan Tempo (Angga Yunanda)", dan "Skenario Pilihan Tempo (Gina S. Noer)". Penghargaan terakhir yang diperoleh oleh film "Dua Garis Biru" yaitu terpilih sebgarai Film Pilihan Asumsi 2019 oleh website Asumsi dan media. Hingga hari akhir penayangan dari film "Dua Garis Biru" diseluruh Indonesia film ini mampu menarik perolehan penonton sebanyak 2.538.363 penonton dari seluruh bioskop yang tersebar dari seluruh kota di Indonesia (Syarifa \& Nugroho, 2020).

Dalam penelitian ini, film Dua Garis Biru diambil sebagai objek penelitian karena mengusung isu yang tabu dalam masyarakat. Karena menceritakan tentang pergaulan bebas remaja yang mengakibatkan terjadinya kehamilan dimasa remaja yang mengharuskan mereka menikah di usia dini. Menurut Gina S. Noer sebagai sutraDara dan penulis, film ini dibuat untuk memberikan pesan seputar sesk edukasi, dirinya merasa perlu adanya edukasi positif untuk para remaja yang ada di Indonesia. (Pertiwi et al., 2020). Film ini tidak hanya memberikan resiko atau konsekuensi dari tindakan - tindakan ceroboh yang dilakukan remaja atau yang mereka alami, namun juga " menyindir " para orang tua agar mereka lebih memperhatikan dan mendapingin anak - anaknya. Dari hasil pemaparan diatas peneliti tergerak untuk meneliti film ini karena tema yang diangkat bisa membuat penonton lebih berfikir tentang bahayanya pergaulan bebas dan dampak yang ditimbulkan sesudahnya, dan di dalam film ini pun terdapat beberapa pesan moral yang penting untuk disampaikan kepada masyarakat khususnya para orang tua untuk lebih memperhatikan anak - anak nya.

\section{METODE PENELITIAN}

Penelitian dalam Film Dua Garis Biru menggunakan metode pendekatan Deskriptif Kualitatif. Menurut Arikunto penelitian deskriptif adalah penelitian yang 


\section{RESEPSI REMAJA TERHADAP DAMPAK PERGAULAN}

BEBAS DI DALAM FILM DUA GARIS BIRU

mengumpulkan data berdasarkan faktor - faktor yang mendukung objek penelitian, kemudian faktor - faktor itu dianalisis untuk dicari peranannya (Prabowo \& Heriyanto, 2013).

Penelitian kualitatif yaitu penelitian yang berhubungan dengan persepsi, ide, pendapat, dan kepercayaan orang yang akan diteliti serta tidak dapat diukur dengan angka. Dalam penelitian ini, teori yang digunakan dalam penelitian ini tidak dipaksakan untuk mendapat gambaran seluruhnya mengenai sudut pandang manusia atau informan yang telah diteliti (Prabowo \& Heriyanto, 2013).

Pemilihan subjek penelitian, peneliti menggunakan metode purposive sampling sejumlah 6 orang remaja mulai dari usia 18 tahun sampai 23 tahun yang pernah menonton film "Dua Garis Biru", 3 orang mahasiswa dan 3 orang masyarakat umum yang usianya dibawah 23 tahun. Metode purposive sampling menurut Sugiyono, yaitu teknik yang penentuan informan berdasarkan kriteria tertentu (Mukhsin et al., 2017). Demi mendapatkan jawaban yang dapat menjawab permasalahan penetilian.

Data yang telah diperoleh dari hasil wawancara, kemudian akan diolah serta pengolahan data tersebut akan dilakukan dengan triangulasi, reduksi, penyajian data dan penarikan kesimpula dengan menggunaka teori yang relevan. Triangulasi adalah teknik pemeriksaan validasi data yang memanfaatkan suatu hal yang lain diluar data untuk pembanding terhadap data tersebut. Ada tiga jenis triangulasi yaitu triangulasi dengan teknik, triangulasi dengan waktu, dan triangulasi dengan sumber. Dalam penelitian ini penulis menggunakan triangulasi sumber yaitu dengan cara memvalidasi data yang telah diperoleh dari sumber. Maka data yang didapat diujikan kepada penonton remaja yang telah menonton film Dua Garis Biru yang merupakan subjek dari penelitian. Kemudian Reduksi adalah teknik merangkum yang mengarahkan serta memfokuskan pada hal - hal yang penting dan membuat yang tidak perlu. Dengan begitu data yang di reduksi dapat memberikan gambaran yang lebih jelas. Dalam penelitian ini, peneliti memfokuskan pada Resepsi Remaja terhadap Pergaulan Bebas yang terdapat dalam film Dua Garis Biru. Lalu penyajian Data adalah langkah berikutnya untuk menyajikan data. Data dapat disajikan berupa sebuah teks yang bersifat naratif. Data disajikan dengan cara mengelompokan masing-masing data yang terdapat didalam penelitian.

Penarikan Kesimpulan adalah langkah berikutnya untuk mendapatkan hasil dari penelitian atau kesimpulan. Setelah menjelaskan data yang telah didapat, peneliti membuat kesimpulan yang hasil dari penelitian.

\section{HASIL DAN PEMBAHASAN}

Pada tahapan pertama dari analisis penelitian ini adalah menganalisis data lalu menginterpretasikannya dari hasil wawancara yang 


\section{RESEPSI REMAJA TERHADAP DAMPAK PERGAULAN}

\section{BEBAS DI DALAM FILM DUA GARIS BIRU}

sebelumnya dilakukan secara mendalam, dalam penelitian resepsi ini tidak ada perbedaan yang khusus antara interpretasi khalayak dan peneliti terhadap pengalaman media masing - masing. Setelah itu hasil data dari wawancara akan dibuat transkrip, lalu dikategorikan berdasarkan tema yang muncul pada pemaknaan yang nanti dilakukan dari subjek penelitian. Pada tahapan kedua adalah tema-tema yang muncul kemudian akan dianalisis dengan cara mempertimbangkan proses dari pemaknaan nanti, cara pemaknaan, karakteristik individu, sekaligus konteks kultural dan social yang melingkupi proses pemaknaan. Dibagian ini tidak hanya analisis dari wawancara saja, akan tetapi studi juga akan diakronik dengan menggunakan prinsip interteks dari analisis wacana, yang dimana wacana dari masyarakat akan diinterpretasikan dengan mempertimbangkan konteks baik dari wacana teks media maupun konteks social, dan kondisi psikologis dari masyarakat. Pada tahapan ketiga yaitu tema-tema yang muncul akan dikelompokkan kedalam tiga kelompok pemaknaan, yaitu : dominant position, negotiated position, dan oppositional posisition.

Dalam penelitian ini, peneliti bermaksud menganalisis 5 adegan dalam film Dua Garis Biru. Adegan pertama adalah adegan dimana Bima dan Dara sedang bermain didalam kamar sampai akhirnya terjadi kejadian yang tidak seharusnya terjadi yaitu melakukan hubungan diluar nikah. Lalu pada adegan kedua terjadi setelah melakukan hubungan diluar nikah, ketika Dara terlihat menyesal dan sedih karena telah melakukan kesalahan yang fatal bersama Bima. Lalu di adegan ketiga dimana Dara sedang melakukan test kehamilan di dalam kamar mandi dan ternyata setelah melakukan test hasilnya positif hamil dan terlihat Dara dan Bima kebingungan karena harus berbuat apa dan mengatakan apa kepada kedua orang tua mereka. Lalu di adegan keempat Dara dan Bima mencoba menggugurkan kandungannya, namun Dara merubah pikiran untuk tidak melakukan itu. Dan di adegan kelima akhirnya orang tua Dara dan Bima mengetahui bahwa Dara hamil sehingga kekecewaan kedua orang tua nya pun memuncak ketika di UKS sekolah.

1. Informan satu

Pada adegan pertama dalam film Dua Garis Biru, informan berpendapat bahwa itu tidak masuk kedalam pergaulan bebas. Pada adegan kedua, informan berpendapat pasti ada rasa penyesalan, karena ada masa depan yang terenggut, contohnya mengubur impian untuk lanjut kuliah dan masa muda yang harus diisi dengan terus bekerja. Pada adegan ketiga, informan berpendapat pasti depresi dan bingung, menyesal kenapa harus melakukan hubungan diluar menikah, karena pasti belum siap untuk menerima konsekuensi yang akan diterima nanti. Pada adegan keempat, informan berpendapat apa yang dilakukan Dara benar untuk tidak melakukan aborsi, karna akan menambah beban baru dan masalah baru, jadi lebih baik menganggung semua resiko yang telah diperbuat dari pada harus mengorbankan anak yang tidak bersalah nantinya. Pada adegan kelima, informan berpendapat pasti kecewa dan akan meminta maaf karena telah mengecewakan 


\section{RESEPSI REMAJA TERHADAP DAMPAK PERGAULAN}

BEBAS DI DALAM FILM DUA GARIS BIRU

orang tua, dan tetapi harus bersedia bertanggung jawab atas apa yang telah diperbuat, dan siap menerima semua resiko sekalipun tidak dianggap anak lagi. Dengan demikian informan satu ketika pada adegan pertama dalam film Dua Garis Biru berada pada tipe oppositional position karena pendapat yang dikemukakannya tidak menyetujui adegan pertama termasuk kedalam pergaulan bebas remaja sedangkan pada adegan dua sampai lima informan berada pada tipe hegemony dominant karena pendapat yang dikemukakannya setuju terhadap makna dari dampak pergaulan bebas yang digambarkan dalam film Dua Garis Biru.

2. Informan dua

Pada adegan pertama dalam film Dua Garis Biru, informan berpendapat itu masuk kedalam pergaulan bebas namun dalam segi hubungan diluar nikah, karena menurut informan pergaulan bebas atau hubungan pra-nikah tidak selalu harus dikamar, tetapi bisa dimana saja tergantung situasi dan kondisi. Pada adegan kedua, informan berpendapat pasti ada rasa perasaan menyesal, tapi tergantung orangnya, karena jika orangnya sudah terbiasa melakukan hubungan diluar nikah, pasti biasa saja, hanya awal-awal saja pasti menyesalnya. Pada adegan ketiga, informan berpendapat perasaan bingung pasti ada, bingung harus menyampaikan apa kepada orang tua kalau anaknya menghamili anak orang lain. Pada adegan keempat, informan berpendapat tidak akan melakukan aborsi, karena lebih kepada tanggung jawab atas apa yang diperbuat dan dilakukan. Pada adegan kelima, informan berpendapat akan meminta maaf dan bertanggung jawab, lebih kepada pasrah karena tidak tau harus melakukan apa lagi untuk menjelaskannya karena orang tua pasti kecewa sekali. Dengan demikian informan dua berada pada posisi hegmenony dominant karena informan setuju terhadap makna dari dampak pergaulan bebas yang ada pada film Dua Garis Biru. Dengan demikian informan dua ketika pada adegan kedua berada pada tipe Negotiated Position karena pendapat yang dikemukakannya memiliki kebimbangan atas pendapatnya yang ada pada adegan tersebut sedangkan pada adegan satu,tiga,empat, dan lima informan berada pada tipe hegemony dominant karena pendapat yang dikemukakannya setuju terhadap makna pergaulan bebas yang digambarkan dalam film Dua Garis Biru.

3. Informan 3

Pada adegan pertama dalam film Dua Garis Biru, informan berpendapat adegan itu masuk kedalam pergaulan bebas, karena melakukan hubungan diluar nikah dan berduaan di dalam kamar serta diluar batas kewajaran. Pada adegan kedua, informan berpendapat pasti menyesal, karena awalnya tidak terpikir untuk melakukan hubungan diluar nikah, dan kehormatan wanita yang terenggut dan tidak seharusnya. Pada adegan ketiga, informan berpendapat ya pasti menyesal karena tidak tahu harus bagaimana lagi, tetapi mau tidak mau harus diterima karena itu resiko dari perbuatan sendiri. Pada adegan keempat, informan berpendapat lebih baik tidak diaborsi, lebih baik dilahirkan saja karena kasian anak yang bakal lahir nanti tidak tau menau namun harus menanggung resiko dari orangtuanya, karena sekalipun lelakinya tidak mau bertanggung jawab, lebih baik dibesarin sendiri 


\section{RESEPSI REMAJA TERHADAP DAMPAK PERGAULAN}

BEBAS DI DALAM FILM DUA GARIS BIRU

karena informan percaya masih banyak lelaki baik diluar sana yang masih mau menerimanya dan anaknya nanti. Pada adegan kelima, informan berpendapat pasti bingung harus berbuat apa, karena merasa bersalah telah mengecewakan orang tua dan pasti akan menjelaskan semua apa yang telah terjadi. Dengan demikian informan tiga berada pada tipe hegemony dominant karena pendapat yang dikemukakannya setuju terhadap makna pergaulan bebas yang digambarkan dalam film Dua Garis Biru.

4. Informan 4

Pada adegan pertama dalam film Dua Garis Biru, informan berpendapat bahwa itu masuk kedalam pergaulan bebas, karena masih memakai seragam lalu berduaan didalam kamar dan melakukan hubungan diluar nikah, dan pasti mereka kurang edukasi dan perhatian dari orang tua. Pada adegan kedua, informan berpendapat jika masih sekolah pasti akan sangat menyesal karena tidak bisa melanjutkan sekolah lagi, otomatis mimpi dan cita-cita terkubur atau hilang. Pada adegan ketiga, informan berpendapat pasti akan sangat bingung, pertama masih sekolah dan belum siap untuk menjadi orang tua karena untuk laki-laki pun akan bingung harus bekerja apa dan mengubur masa mudanya. Pada adegan keempat, informan berpendapat tidak akan melakukan aborsi, karena sudah melakukan hubungan diluar nikah itu dosa, lalu mengaborsi kandungan semakin dosa, jadi lebih baik menerima kenyataan. Pada adegan kelima, informan berpendapat pasti akan menanggung resiko dengan apa yang diperbuat dan meminta maaf kepada orang tua, karena penyesalan akan selalu datang diakhir dan mau tidak mau harus menerima resiko yang ada. Dengan demikan informan keempat berada pada tipe hegemony dominant karena pendapat yang dikemukakannya setuju terhadap makna pergaulan bebas yang digambarkan dalam film Dua Garis Biru.

5. Informan 5

Pada adegan pertama dalam film Dua Garis Biru. Informan berpendapat bahwa itu masuk ke dalam kategori pergaulan bebas karena mereka posisinya berada di ranjang Kasur dan berduaan terus posisi mereka juga kan si cewenya diatas cowonya diatas itu kan jelas masuk ke pergaulan bebas karena dalam suatu hubungan kaya gitu ya ga wajar aja tiduran di ranjang berduaan ya pastinya kan menjurus ke arah adegan dewasa.Pada adegan kedua dalam film Dua Garis Biru, Informan berpendapat bahwa pastinya akan sangat menyesal karena apa yang sudah dilakukan itu bisa menghambat semuanya mulai dari pendidikan,cita-citanya dan semua mimpinya pasti akan terkubur dan gabakal tercapai. Pada adegan ketiga informan berpendapat bahwa dirinya pasti malu jika mengalami hal yang sama seperti adegannya yaitu hamil diluar nikah,dirinya merasakan bahwa kejadian tersebut pasti akan merengggut semua yang dirinya inginkan dan merasa malu oleh lingkungan sekitarnya.Pada adegan keempat, informan berpendapat bahwa dirinya tidak akan melakukan prilaku yang keji yaitu dengan cara mengaborsi janinnya karena anak yang berada didalam janinnya itu tidak memiliki kesalahan apapun justru kedua orang tuanya yang berbuat prilaku seperti itu harus berani bertanggung 


\section{RESEPSI REMAJA TERHADAP DAMPAK PERGAULAN}

BEBAS DI DALAM FILM DUA GARIS BIRU

jawab atas apa yang dilakukannya. Pada adegan kelima, informan berpendapat bahwa pasti jika dirinya diposisi itu akan menerima segala resiko yang akan terjadi,dirinya akan bersikap jujur kepada orang tuanya walaupun itu pasti dapat membuat hati kedua orang tua dirinya menjadi sakit atas tingkah laku dirinya,dan memohon kepada orang tuanya untuk menerimakan kejadian ini dan menyetujuinya untuk dilanjutkan ke jenjang pernikahan. Dengan demikian informan kelima berada pada tipe Hegemony Dominant karena pendapat yang dikemukakannya setuju terhadap makna pergaulan bebas yang digambarkan dalam film Dua Garis Biru.

6. Informan 6

Pada adegan pertama dalam film Dua Garis Biru, Informan berpendapat itu masuk kedalam pergaulan bebas, karena apa yang dilakukan berdasarkan keinginan sendiri dan berbuat diluar batas sebelum menikah. Pada adegan kedua, informan berpendapat, tergantung masing - masing orangnya, karena jika sama - sama mau pasti tidak akan menyesal, tapi jika ada yang terpaksa pasti akan menyesal. Pada adegan ketiga, informan berpendapat harus bertanggung jawab atas apa yang telah diperbuat, jika setiap orangnya mau sama - sama menanggung resiko yang telah diperbuat. Pada adegan keempat, informan berpendapat tidak akan pernah sekalipun berfikir untuk aborsi, karena kasian kepada wanitanya dan anaknya nanti, dan jika ada yang menyuruh untuk aborsi itu lelaki sangat kejam dan tidak mempunyai hati. Pada adegan kelima, informan berpendapat jelas pasti sedih karena orang tua pasti akan merasa gagal dalam mendidik anaknya, dan pasti malu karena anaknya hamil diluar nikah. Dengan demikian informan keenam ketika pada adegan kedua berada pada tipe Negotiated Position karena pendapat yang dikemukakannya memiliki kebimbangan yang ada pada adegan tersebut, sedangkan pada adegan satu, tiga, empat, dan lima informan berada pada tipe Hegemony Dominant karena pendapat yang dikemukakannya setuju terhadap makna pergaulan bebas yang digambarkan dalam film Dua Garis Biru.

\section{KESIMPULAN \& SARAN}

\section{Kesimpulan}

Berdasarkan dari hasil penelitian yang peneliti lakukan melalui wawancara mendalam dan observasi mengenai pembacaan (Resepsi) masyarakat tentang pemaknaan dampak pergaulan bebas pada remaja dalam film Dua Garis Biru bahwa penonton dalam penerimaan mereka tentang makna dampak pergaulan bebas remaja dalam film Dua Garis Biru didominasi oleh Hegemony Dominant. Dari kelima adegan yang diteliti, empat diantaranya berada di hegemony dominant mutlak dalam dua scene lainnya informan ada dalam posisi negosiated position dan oppositional position. Yang dimana dalam setiap adegan menampilkan materi dampak pergaulan bebas yang berbeda - beda.

\section{Saran}




\section{RESEPSI REMAJA TERHADAP DAMPAK PERGAULAN}

BEBAS DI DALAM FILM DUA GARIS BIRU

Berdasarkan kesimpulan yang telah disampaikan sebelumnya, peneliti akan memberikan saran - saran sebagai berikut :

1. Saran Akademis

Disarankan untuk peneliti selanjutnya, dapat menggunakan objek lain seperti media cetak dan televisi.

2. Saran Praktis

Peneliti berharap film ini dijadikan contoh agar tidak terjadi dikehidupan seharihari dan dilingkungan sekitar,

serta diperlukannya bimbingan dan perhatian dari orang tua terhadap pergaulan anaknya.

\section{DAFTAR PUSTAKA}

Kartika, P. C. (2017). JURNAL PENA INDONESIA Jurnal Bahasa dan Sastra Indonesia serta Pengajarannya. Jurnal Bahasa Dan Sastra Indonesia Serta Pengajarannya, 3(1), 42-58.

Malang, universitas muhammadiyah. (2012). Film sebagai media komunikasi massa. 1982, 6-26.

Mukhsin, R., Mappigau, P., \& Tenriawaru, A. N. (2017). Pengaruh Orientasi Kewirausahaan Terhadap Daya Tahan Hidup Usaha Di Kota Makassar. Jurnal Analisis, 6(2), 188-193.

http://pasca.unhas.ac.id/jurnal/files/ef79bd330d16ba9fda32510e0a581953.pdf

Pertiwi, M., Ri’aeni, I., \& Yusron, A. (2020). Analisis Resepsi Interpretasi Penonton terhadap Konflik Keluarga dalam Film "Dua Garis Biru." Jurnal Audiens, 1(1), 18. https://doi.org/10.18196/ja.1101

Prabowo, A., \& Heriyanto. (2013). Analisis Pemanfaatan Buku Elektronik (E-Book)

Oleh Pemustaka di Perpustakaan SMA Negeri 1 Semarang. Jurnal Ilmu

Perpustakaan, 2(2), 1-9. http://ejournal-

s1.undip.ac.id/index.php/jip\%5CnANALISIS

Syarifa, S. N., \& Nugroho, C. (2020). Penerimaan Pesan Seks Pranikah Oleh Penonton Dalam Film Dua Garis Biru. JCommsci - Journal Of Media and Communication Science, 3(2), 92-114. https://doi.org/10.29303/jcommsci.v3i2.70

Tambunan, N. (2018). Pengaruh Komunikasi Massa terhadap Khalayak The Effect of Mass Communication on the Audience. 4(1), 24-31. 